\title{
Effect of paclobutrazol on growth and fruit characteristics of ornamental pepper (Capsicum annum $\mathbf{L}$.)
}

\author{
Aijaz Ali Baloch ${ }^{1}$, Nadir Ali ${ }^{2}$, Zafar Ullah ${ }^{2 *}$, Kaleemullah ${ }^{2}$, Siraj \\ Ahmad $^{2}$, Honak Baloch ${ }^{3}$, Adul Jabbar ${ }^{4}$, Adul Razzaq Reki ${ }^{2}$, Sulaman \\ Jaffar $^{2}$ and Zia-ul-haq ${ }^{2}$ \\ 1. Sindh Agriculture University, Tandojam-Pakistan \\ 2. Balochistan Agriculture College, University of Balochistan Quetta-Pakistan \\ 3. Lasbela University of Agriculture, Water and Marine Sciences, Uthal-Pakistan \\ 4. Directorate of Agriculture Research, Wayaro Farm Uthal, Lasbela-Pakistan \\ zumalghani@gmail.com \\ *Corresponding author's email:_zumalghani@gmail.com \\ Citation \\ Aijaz Ali Baloch, Nadir Ali, Zafar Ullah, Kaleemullah, Siraj Ahmad, Honak Baloch, Adul Jabbar, Adul Razzaq \\ Reki, Sulaman Jaffar and Zia-ul-haq. Effect of paclobutrazol on growth and fruit characteristics of ornamental \\ pepper (Capsicum annum L.). Pure and Applied Biology. Vol. 8, Issue 4, pp2302-23120. \\ http://dx.doi.org/10.19045/bspab.2019.80177
}

\begin{tabular}{llll}
\hline \hline Received: 30/03/2019 & Revised: 07/07/2019 & Accepted: 23/07/2019 & Online First: 03/08/2019 \\
\hline \hline
\end{tabular}

\section{Abstract}

The experiment was carried out to examine the effect of paclobutrazol on growth and fruiting characteristics of ornamental pepper (Capsicum annum L.). The aim of the study was to determine the paclobutrazol concentrations on economical yield of ornamental pepper. Paclobutrazol levels were Control, 30, 60, 90, 120 and $150 \mathrm{mg}$ ai (active ingredients) $\mathrm{L}^{-1}$. Before flowering there were three applications of paclobutrazol applied at interval of 10 days. The lowest number of flowers plant ${ }^{-1}$ was recorded under control treatment. The highest number of fruits was observed at the rate of $150 \mathrm{mg}$ ai $\mathrm{L}^{-1}$ paclobutrazol. The highest $(3.17 \mathrm{~g})$ weight of single fruit was observed at $150 \mathrm{mg}$ active ingredients $\mathrm{L}^{-1}$ paclobutrazol. The lowest weight of single fruit $30 \mathrm{mg}$ active ingredients $\mathrm{L}^{-1}$ paclobutrazol was recorded under control treatment. The highest 56 days taken to opening of first flower was observed under the control whereas the palobutrazol increased the level up to $30 \mathrm{mg}$ active ingredients $\mathrm{L}^{-1}$ was observed 53.33 days taken to opening of first flower. However, the highest (31.33) duration of fruiting was observed under $150 \mathrm{mg}$ active ingredients $\mathrm{L}^{-1}$ paclobutrazol. It was concluded that higher paclobutrazol concentration up to $150 \mathrm{mg}$ active ingredients $\mathrm{L}^{-1}$ remained obviously better overall other treatments, but the differences for almost all the parameters between 120, 90, 60 and 30 $\mathrm{mg}$ ai $\mathrm{L}^{-1}$ paclobutrazo concentration were significant.

Keywords: Capsicum annum; Fruit; Growth; Growth Retardants; Ornamental pepper; Paclobutrazol Introduction

Ornamental pepper (Capsicum annuum L.) belongs to the Solanaceae family, which is mainly a tropical family. Ornamental pepper is cultivated broadly and economically important species of peppers and is used as a vegetable pepper, sweet pepper, dried hot peppers, chilli powder, paprika, as and ornamental crop [1]. Ornamental peppers are popular herbaceous species because of the pod types diversity and habit of plant. There are three main types of ornamental peppers: such as potted, cut stems and bedding. The Cut stems are popular in Europe. Whereas, in the USA gaining popularity in the recent years. This type of pepper produces clusters of fruits on long stems capable for use in flower arrangements. Other ornamental peppers which are heat and 
drought tolerant or prostrate are grown as bedding and garden plants. Some ornamental peppers are used for both ornamental and culinary purposes [2].

The use of ornamental peppers as a potted plants exhibit advantages like easy seed propagation, heat and drought tolerance, short cycle production, fruit production and excellent performance of postharvest [3]. However, drench and foliar applications of paclobutrazol have been studied on growth control of ornamental plant production [4]. Despite the use of paclobutrazol in the industry of potted plants, few studies have been published concerning paclobutrazol efficacy for ornamental peppers.

Excessive plant growth may often cause untimely pollination, reduced fruit set and as well as greater incidence of misshapen fruits [5]. Under circumstances when there is excessive growth of plants the fruit yields are reduced. Moreover, due to imbalanced nutrients in the soil the vegetative growth is rapidly increased but the yields are not improved alike. Paclobutrazol is an inhibitor of gibberellins biosynthesis applied as soil drench. Generally it is experienced that application of Paclobutrazol suppressed the vegetative growth of pepper and increased fruit yield [6]. Many other plant growth regulators, the paclobutrazol has an advantage which can be effective when initially incorporated in the potting compost or when used in soil drench or sprayed on the foliage, as done in the chrysanthemum field. Paclobutrazol is slowly metabolized in plants from the base toward the apex via the xylem which may act as a pool for this application taken up by roots, thus prolonging persistence [7].

Paclobutrazol is a substance that inhibits the growth and triazole fungicide. It is a known opponent of the plant hormone gibberellins. It acts by restraining gibberellins biosynthesis, reducing internodial growth to give strong stems, increasing root growth, increasing seed set and causing early fruit set in plants such as pepper and tomato. It has also been shown to decrease frost sensitivity in plants. This growth initiator is used by arborists to decrease growth of shoot and has been shown to have additional positive effects on shrubs and trees. Among those are enhanced drought stress resistance, darker green leaves, resistance to against bacteria and fungi, and reduced roots development [8]. Paclobutrazol is normally applied to the soil to be taken up by the roots and transported via the xylem to the upper parts of the plant. Foliar application is mostly unsuccessful [9]. Seeds can be soaked with paclobutrazol to decrease growth of seedling [10]. Abdollahi et al. [11], reported that the application of paclobutrazol increased root fresh weight as well as such reproductive growth, number of fruits and inflorescences, but it was accompanied by a decrease in fruit size in strawberry which proved that paclobutrazol is a triazol that promotes reproductive growth by reducing vegetative growth.

For many years, by using chemical methods to control growth, to improve aesthetical effects on potted ornamental plants has been studied. Application of growth inhibitors is a common practice to achieve attractive compact potted grown plants for commercial growers. Researchers have reported that paclobutrazol ([2RS,3RS]-1-[4chlorophenyl]-4,-4-dimethyl-2-[1,2,4triazol-1-yl]pentan-3-ol), a triazole plant growth regulator, has been determined to be effective in controlling vegetative growth and promoting compactness in the production of a number of ornamental plants including, Lilium longiflorum [12], and potted ornamental peppers [13]. Christiane et al. [14], investigated that significant earliness in harvest maturity was found in paclobutrazol treated plants but total yield differences were recorded no significant between the paclobutrazol and control plants. Giovinazzo et al. [15], observed $13 \%$ increases significant yield due to the paclobutrazol treatments together with earlier harvest maturity by 
$6 \%$. Therefore, the proposed study was carried out to determine the effect of paclobutrazol on growth and fruit characteristics of ornamental pepper. Objectives of the research were: to investigate the effect of different concentrations of paclobutrazol on the growth attributes of ornamental pepper and to examine the fruiting response of ornamental pepper to paclobutrazol at different concentrations.

\section{Materials and methods}

The pot experiment was accomplished on the effect of paclobutrazol on growth and fruit characteristics of ornamental pepper at the Horticulture orchard, Sindh Agriculture University, Tandojam during the year 2013-14. The ornamental pepper seedling was transplanted in pots. Each treatment was comprised of 10 plants.

The trial was implemented on $12^{\text {th }}$ march 2014 , when temperature was around $25^{\circ} \mathrm{C}$ \pm , certified and hybrid seeds were sown in pots comprising size of 10-12 inches with 6 treatments and 3 replications, each treatment was comprised on 30 plants and 10 plants in each replication. Germination was occurring in 5-7 days after sowing. Transplanted seedlings into trail pots after 43 days, when seedlings were attained to 34 inches. $1^{\text {st }}$ irrigation was at interval of 3 days when pots were covered with plastics, $2^{\text {nd }}$ irrigation was at 1 day interval when pots were uncovered. Weeding and hoeing was done after every 7 days. Before flowering 3 applications of paclobutrazol were applied to plants when size seedlings were reached to height of $4-5 \mathrm{~cm}$, after that interval was extended to every 10 days. Six treatments (Paclobutrazol levels) were $\mathrm{T}_{1}$ (Control), $\mathrm{T}_{2}$ (30 $\mathrm{mg}$ ai $\left.\mathrm{L}^{-1}\right), \mathrm{T}_{3}(60 \mathrm{mg}$ ai $\left.\mathrm{L}^{-1}\right), \mathrm{T}_{4}\left(90 \mathrm{mg}\right.$ ai $\left.\mathrm{L}^{-1}\right), \mathrm{T}_{5}\left(120 \mathrm{mg}\right.$ ai $\mathrm{L}^{-}$ $\left.{ }^{1}\right)$ and $\mathrm{T}_{6}\left(150 \mathrm{mg}\right.$ ai $\left.\mathrm{L}^{-1}\right)$. Parameters were $v i z$ : Number of flowers plant ${ }^{-1}$, Number of branches plant ${ }^{-1}$, Height of plant $(\mathrm{cm})$, Number of fruits plant ${ }^{-1}$, Size of fruits $(\mathrm{cm})$, Weight of single fruits $(\mathrm{g})$, Days taken to opening of first flower, Duration of fruiting and Life cycle of plant

\section{Statistical analysis}

The data was statistical analysis to distinction the supremacy of treatment means, using LSD (Least Significant Differences) test, as per the statistical methods developed by [16], using MSTAT-C Computer Software. The experiment was laid out in Complete Randomized Design (CRD).

\section{Results and discussion}

Number of flowers plant ${ }^{-1}$

The data regarding number of flowers plant $^{-1}$ as affected by different paclobutrazol levels are presented in Table 1. The results of DRMT (disaggregated Reconfigurable Match-Action Table) at probability less than $0.05 \quad(\mathrm{P}>0.05)$, illustrated that the number of flowers plant 1 was non-significantly under increasing paclobutrazol combination levels. However, the highest (49.03) number of flowers plant ${ }^{-1}$ was observed under $120 \mathrm{mg}$ ai $\mathrm{L}^{-1}$ paclobutrazol, and minimum number of (33.20) flowers plant ${ }^{-1}$ was observed under control treatment.

The results on number of days from flower initiation up to full bloom indicated that the application of chemical Paclobutrazol had no significant effect in extending number of days from flower initiation up to full bloom of the mango plants, since all racemes gave a similar period of full bloom, whilst the fruit dropping percentage was significantly affected by different rates of PBZ. These findings are in accordance with [17], studied the effect of pinching and paclobutrazol at the rate of 20,40 and $60 \mathrm{ppm}$ (parts per million) on growth, flowering, histological characteristics and chemical compositions of potted plant. Results showed that: All pinching and paclobutrazol concentrations decreased plant height compacting showy plants, particularly the combined treatment of paclobutrazol at the rate of $60 \mathrm{ppm}$ with pinching in both seasons. On the other hand, all applied treatments of pinching and paclobutrazol statistically increased number of branches plant $^{-1}$ to reach its maximum with the highest concentration for each. The heaviest fresh and dry 
weights of leaves plant $^{-1}$, the highest number of flowers plant ${ }^{-1}$ were gained from plants pinched and sprayed by paclobutrazol at $60 \mathrm{ppm}$ in the two seasons. Consequently, Chutichudet et al [18], accounted that information on the effect of chemical Paclobutrazol on flower and fruit development, quality and fruit yield of Kaew variety of mango. Its flowering period was initiated in late November 2004 and then spraying of different rates of chemical Paclobutrazol was carried out accordingly. They found maximum number of flowers plant ${ }^{-1}$ at 120 and $150 \mathrm{mg}$ ai $\mathrm{L}^{-1}$ of paclobutrazol.

\section{Number of branches plant ${ }^{-1}$}

The data regarding mean number of branches plant ${ }^{-1}$ as affected by different paclobutrazol levels are presented in (Table No. 1). The results illustrated that the number of branches plant ${ }^{-1}$ was significantly $(\mathrm{P}<0.05)$ influenced under increasing paclobutrazol combination levels. The maximum branches (8.83) plant $^{-1}$ in chillies were observed in plants given $150 \mathrm{mg}$ ai $\mathrm{L}^{-1}$ paclobutrazol whereas the lowest number of branches (5.93) was recorded under control treatment. However, adverse effects on number of branches plant $^{-1}$ were noted that the paclobutrazol was applied at the concentration of $120 \mathrm{mg}$ ai $\mathrm{L}^{-1}$ and the plant developed (8.16) number of branches plant $^{-1}$. The results further revealed that the number of branches was recorded 7.93 where $90 \mathrm{mg}$ ai $\mathrm{L}^{-1}$ paclobutrazol was applied. However, paclobutrazol at the rate of 60 and $30 \mathrm{mg}^{2}$ ai $\mathrm{L}^{-1}$ was recorded $(7.00$ and 6.46) number of branches. The DMRT indicated similarity $(\mathrm{P}>0.05)$ in number of branches plant ${ }^{-1}$ under the concentration of paclobutrazol 90 and $60 \mathrm{mg}$ ai $\mathrm{L}^{-1}$.

The obtained results revealed that application of PBZ at $30 \mathrm{mg}$ ai $\mathrm{L}^{-1}, 60 \mathrm{mg}$ ai $\mathrm{L}^{-1}, 90 \mathrm{mg}$ ai $\mathrm{L}^{-1}, 120 \mathrm{mg}$ ai $\mathrm{L}^{-1}$ and 150 $\mathrm{mg}$ ai $\mathrm{L}^{-1}$ created significant stimulative effects on number of branches plant ${ }^{-1}$ of ornamental pepper. These results are confirmed by Khan et al. [19], evaluated that paclobutrazol, an inhibitor of gibberellin biosynthesis was applied as soil drench to the pepper "Serano" in green house. Drenching was done one week after transplanting at 0,200 and $400 \mathrm{ppm}$. There was no effect on fruit weight at $200 \mathrm{ppm}$ but, at $400 \mathrm{ppm}$ it reduced significantly. Plant growth, height and internodal distance were reduced with darker and thicker leaves. However additionally evidence confirmed the findings accordingly with [20], the obtained results revealed that application of paclobutrazol at 50 and $100 \mathrm{ppm}$ created significant simulative effects on growth parameters of eggplants. These effects were clear with the resulted induced decreases in shoots and root lengths; but increase the number of branches, number leaves plant $^{-1}$.

Table 1. Effect of different levels of paclobutrazol on number of flowers plant ${ }^{-1}$ number of branches (plant $\left.{ }^{-1}\right)$, plant height $(\mathrm{cm})$, number of fruits and size of

\begin{tabular}{|c|c|c|c|c|c|}
\hline Treatments & $\begin{array}{c}\text { Number of } \\
\text { Flowers } \\
\text { plant }^{-1} \\
\end{array}$ & $\begin{array}{c}\text { Number of } \\
\text { branches }^{-1} \\
\left.\text { (plant }^{-1}\right)\end{array}$ & $\begin{array}{l}\text { Plant height } \\
\text { (cm) }\end{array}$ & $\begin{array}{l}\text { Number } \\
\text { of fruits }\end{array}$ & $\begin{array}{c}\begin{array}{c}\text { Size of } \\
\text { fruit } \\
(\mathbf{c m})\end{array} \\
\end{array}$ \\
\hline $\mathrm{T}_{1}$ control & $33.20 \mathrm{~d}$ & $5.93 \mathrm{~d}$ & $14.66 \mathrm{a}$ & $19.58 \mathrm{c}$ & $5.00 \mathrm{a}$ \\
\hline $\mathrm{T}_{2} 30 \mathrm{mg}$ ai $\mathrm{L}^{-1}$ & $39.40 \mathrm{~cd}$ & $6.46 \mathrm{~cd}$ & $11.06 \mathrm{~b}$ & $25.81 \mathrm{ab}$ & $5.00 \mathrm{a}$ \\
\hline $\mathrm{T}_{3} 60 \mathrm{mg}$ ai $\mathrm{L}^{-1}$ & $42.53 \mathrm{~cd}$ & $7.00 \mathrm{bcd}$ & $9.86 \mathrm{bc}$ & $26.96 \mathrm{ab}$ & $4.33 \mathrm{~b}$ \\
\hline $\mathrm{T}_{4} 90 \mathrm{mg}$ ai $\mathrm{L}^{-1}$ & $47.13 \mathrm{~b}$ & $7.93 \mathrm{abc}$ & $8.93 \mathrm{~cd}$ & $24.22 \mathrm{bc}$ & $4.60 \mathrm{ab}$ \\
\hline $\mathrm{T}_{5} 120 \mathrm{mg}$ ai $\mathrm{L}^{-1}$ & $49.03 \mathrm{a}$ & $8.16 \mathrm{ab}$ & $8.73 \mathrm{~cd}$ & $30.40 \mathrm{a}$ & $4.73 \mathrm{ab}$ \\
\hline $\mathrm{T}_{6} 150 \mathrm{mg}$ ai $\mathrm{L}^{-1}$ & $48.23 \mathrm{ab}$ & $8.83 \mathrm{a}$ & $7.73 \mathrm{~d}$ & $31.27 \mathrm{a}$ & $4.80 \mathrm{ab}$ \\
\hline
\end{tabular}

$\mathrm{NS}^{*}=$ Non-significant and Values with different letters differ significantly 


\section{Plant height (cm)}

The data regarding mean plant height $(\mathrm{cm})$ as affected by various paclobutrazol levels are manifested in Table 1 . The results illustrated that the plant height $(\mathrm{cm})$ was significantly $(\mathrm{P}<0.05)$ influenced under increasing paclobutrazol combination levels. Moreover, the results showed the highest $(14.66 \mathrm{~cm})$ plant height was observed under the control treatment while the lowest $(7.73 \mathrm{~cm})$ plant height was recorded under the concentration of paclobutrazol at the concentration of 150 $\mathrm{mg}$ ai $\mathrm{L}^{-1}$. However the plant was treated under the concentration of $30 \mathrm{mg}$ ai $\mathrm{L}^{-1}$ paclobutrazol was observed (11.06) plant height. On other hand the plant was treated with $60 \mathrm{mg}$ ai $\mathrm{L}^{-1}$ paclobutrazol was recorded $(9.86 \mathrm{~cm})$ plant height. The plant was treated with $90 \mathrm{mg}$ ai $\mathrm{L}^{-1}$ paclobutrazol were noted (8.93) plant height. Whereas the crop was treated with $120 \mathrm{mg}^{2}$ ai $\mathrm{L}^{-1}$ was gave $(8.73 \mathrm{~cm})$ plant height.

The treatments of paclobutrazol respond effective results. According to these investigators, moraes et al. [21], examined that the ornamental tomato growth and fruiting response to paclobutrazol. The experiment was conducted in two parts; in a part one, paclobutrazol was applied as a foliar spray and Plant height was 20\% shorter, when paclobutrazol concentrations spray increased up to $30 \mathrm{mg}$ ai $\mathrm{L}^{-1}$. Besides this the investigations of [22], reduced height and the increased thickness of the young plant stem, as well as the accelerated root formation are a significant advantage of the PBZ treatment, contributing to the improvement of seedling quality at planting improve was due to the photosynthetic activity and water balance of tomato.

\section{Number of fruits}

The data regarding mean number of fruits as responded by various paclobutrazol levels are exhibited in (Table No. 1). The results illustrated that the number of fruits was significantly $(\mathrm{P}<0.05) \quad$ influenced under increasing paclobutrazol concentrations. The highest (31.27) number of fruits was observed under the concentration of $150 \mathrm{mg}$ ai $\mathrm{L}^{-1}$ paclobutrazol while the lowest number of fruits (19.58) was recorded under control treatment. $120 \mathrm{mg}$ ai $\mathrm{L}^{-1}$ showed 30.40 numbers of fruits. Whereas the plant was treated with $90 \mathrm{mg}$ ai $\mathrm{L}^{-1}$ paclobutrazol was recorded 24.22 numbers of fruits. On other hand the plant was treated with $60 \mathrm{mg}^{\text {ai } \mathrm{L}^{-}}$ 1 paclobutrazol was observed 25.18 numbers of fruits. Whereas the plant was treated under the concentration of $30 \mathrm{mg}$ ai $\mathrm{L}^{-1}$ paclobutrazol was noted 26.96 numbers of fruits.

The results confirmed the findings and analysis of [11], that the application of paclobutrazol $\mathrm{PP}_{333}$ increased root fresh weight as well as such reproductive growth as number of fruits and inflorescences, but was accompanied by a decrease in fruit size in strawberry; which proved that paclobutrazol is a triazol that promotes reproductive growth by reducing vegetative growth. Furthermore, Lolaei et al. [23], examined the effect of Paclobutrazol on vegetative growth, leaf chlorophyll, time to flowering and harvest, yield and composition of fruit of greenhouse-grown cultivar banana during its first cycle. Paclobutrazol has potent specific inhibitor of $\mathrm{GA}_{3}$ biosynthesis. Paclobutrazol slightly reduced the shoots length and area of leaf reduction by paclobutrazol was reported and increased total leaf chlorophyll content. The influence of paclobutrazol has been investigated to increase the fruit yield and not affected on apple fruit quality, $\mathrm{pH}$, acidity or soluble solid content. Nevertheless, it was also related to the observations of [22], that they studied the physiological effect of the plant growth retardant paclobutrazol and its impact on the yield of tomato plants increased the number of fruit plant ${ }^{-1}$ was due to improves the photosynthetic activity and water balance of this plant. Paclobutrazol accelerates fruit formation and increases early fruit yield. The concentrations of the retardant used and the mode of its 
application ensure the production of fruits without any residual retardant.

\section{Size of fruits (cm)}

The data regarding size of fruits $(\mathrm{cm})$ as affected by different paclobutrazol levels are presented in (Table No. 2). The results of elaborated that the size of fruits $(\mathrm{cm})$ was significantly $(\mathrm{P}<0.05) \quad$ influenced under increasing paclobutrazol concentrations. The highest $(5.00 \mathrm{~cm})$ size of fruits was observed under the control and at the concentration of $30 \mathrm{mg}$ ai $\mathrm{L}^{-1}$ paclobutrazol while the lowest size of fruit $(4.33 \mathrm{~cm})$ was recorded plant was treated with $90 \mathrm{mg}$ ai $\mathrm{L}^{-1}$ paclobutrazol. $150 \mathrm{mg}$ ai $\mathrm{L}^{-1}$ showed 4.80 sizes of fruit. Whereas the plant was treated with $120 \mathrm{mg}$ ai $\mathrm{L}^{-1}$ paclobutrazol was recorded 4.73 sizes of fruits. However, the plant was treated with $90 \mathrm{mg}$ ai $\mathrm{L}^{-1}$ paclobutrazol was showed 4.60 number of fruits.

These obtained results are in harmony with those reported by [24], conducted experiment on paclobutrazol on growth and fruiting characteristics of 'pitanga' ornamental pepper and using container. There were two experiment, one with as a foliar application of canopy and second form enhanced the fruit diameter the collected data also matched with [25].

\section{Weight of single fruit (g)}

The data regarding mean single fruit $(\mathrm{g})$ weight as affected by different paclobutrazol levels are presented in (Table No. 2). The results illustrated that the weight of single fruit $(\mathrm{g})$ was significantly $(\mathrm{P}<0.05) \quad$ influenced under increasing paclobutrazol concentration. The highest $(3.17 \mathrm{~g})$ weight of single fruit was observed under the concentration of 150 $\mathrm{mg}$ ai $\mathrm{L}^{-1}$ paclobutrazol while the lowest weight of single fruit $(2.04, \mathrm{~g}) 30 \mathrm{mg}^{\mathrm{ai} \mathrm{L}^{-1}}$ paclobutrazol was recorded under control treatment where no paclobutrazol was applied. Treatment $120 \mathrm{mg}$ ai $\mathrm{L}^{-1}$ paclobutrazol showed 2.45 weights of single fruit. Whereas the plant was treated with $90 \mathrm{mg}$ ai $\mathrm{L}^{-1}$ paclobutrazol was recorded 2.17 weights of single fruit. However, the plant was treated with $60 \mathrm{mg}$ ai $\mathrm{L}^{-1}$ paclobutrazol was observed 2.16 weight of single fruit.

El-Masry [26], studied that the effect of K levels and paclobutrazol concentrations on the fruit weight of Sweet Pepper (Capsicum annuum). Potassium fertilizer application increased as well as fruit dry weight. While the paclobutrazol along with other chemicals increased fruit dry weight. Chutichudet at al. [27], they investigated that an increase in paclobutrazol application rate highly decreased plant height, harvesting age and significantly decreased leaf area of the fifth leaf but highly increased pod length, fresh weight pod $^{-1}$ and fresh pod yield ha ${ }^{-1}$ of the okra plants. The highest edible pod yield reached as result of highest rate of paclobutrazol application.

Table No. 2 Effect of different levels of paclobutrazol on weight of single fruit (g), days taken to opening of first flower and duration of fruiting and Life cycle plant

\begin{tabular}{|c|c|c|c|cc|}
\hline Treatments & $\begin{array}{c}\text { Weight of } \\
\text { single fruit }(g)\end{array}$ & $\begin{array}{c}\text { Days taken } \\
\text { to opening of first flower }\end{array}$ & $\begin{array}{c}\text { Duration of } \\
\text { fruiting }\end{array}$ & $\begin{array}{c}\text { Life cycle } \\
\text { plant }\end{array}$ \\
\hline $\mathrm{T}_{1}$ control & $1.98 \mathrm{c}$ & $56.00 \mathrm{a}$ & $21.66 \mathrm{~d}$ & 4.26 & $\mathrm{f}$ \\
\hline $\mathrm{T}_{2} 30 \mathrm{mg}$ ai L & $2.04 \mathrm{c}$ & $53.33 \mathrm{~b}$ & $25.00 \mathrm{c}$ & 4.60 & $\mathrm{e}$ \\
\hline $\mathrm{T}_{3} 60 \mathrm{mg}^{-1} \mathrm{~L}^{-1}$ & $2.16 \mathrm{bc}$ & $51.66 \mathrm{c}$ & $25.33 \mathrm{c}$ & $4.93 \mathrm{~d}$ \\
\hline $\mathrm{T}_{4} 90 \mathrm{mg} \mathrm{ai} \mathrm{L}^{-1}$ & $2.17 \mathrm{bc}$ & $50.33 \mathrm{~cd}$ & $27.33 \mathrm{~b}$ & 5.53 & $\mathrm{c}$ \\
\hline $\mathrm{T}_{5} 120 \mathrm{mg} \mathrm{ai} \mathrm{L}^{-1}$ & $2.45 \mathrm{~b}$ & $49.33 \mathrm{~d}$ & $28.00 \mathrm{~b}$ & $5.93 \mathrm{~b}$ \\
\hline $\mathrm{T}_{6} 150 \mathrm{mg}$ ai L & & $3.17 \mathrm{a}$ & $47.66 \mathrm{e}$ & $31.33 \mathrm{a}$ & $6.20 \mathrm{a}$ \\
\hline
\end{tabular}

NOTE; Values with different letters differ significantly 


\section{Days taken to opening of first flower}

The data regarding mean days taken to opening of first flower as affected by different paclobutrazol levels are presented in (Table 2). The results elaborated that the days taken to opening of first flower was significantly $(\mathrm{P}<0.05)$ influenced under increasing paclobutrazol concentration.

The results indicated that the paclobutrazol was applied at the rate of $150 \mathrm{mg}$ ai $\mathrm{L}^{-1}$ was observed lowest (47.66) days taken to opening of first flower of chillies whereas the highest (56.00) days taken to opening of first flower was observed under the control. The palobutrazol increased the level up to $30 \mathrm{mg}$ ai $\mathrm{L}^{-1}$ was observed (53.33) days taken to opening of first flower. The increasing level of paclobutrazol upto $60 \mathrm{mg}$ ai $\mathrm{L}^{-1}$ was recorded 51.66 days taken to opening of first flower. However, the plant was treated with $90 \mathrm{mg}$ ai $\mathrm{L}^{-1}$ paclobutrazol was observed 50.33 days taken to opening of first flower. However the increasing level of paclobutrazol upto $120 \mathrm{mg}$ ai $\mathrm{L}^{-1}$ decrease the (49.33) days taken to opening of first flower of chilli, However the decreasing level of paclobutrazol up to 30 $\mathrm{mg}$ ai $\mathrm{L}^{-1}$ increased the days taken to opening of first flower of chilli.

These obtained outcomes are in accord with those accounted by [17], shows that all tested pinching and PP333 treatments delayed the flowering of Pelargonium zonale L. plants as compared with untreated control plants in both seasons. However, the highest retardation of Pelargonium zonale L. flowering was gained by pinched plants sprayed with 60 ppm PP333 (106.7 and 106.3 days), followed in descending order by pinched plants sprayed with 40 ppm PP333 (101.0 and 101.3 days), in the first and second seasons, respectively. The earliest flowering was occurred by untreated plants control treatment. Thakur et al. [28], worked on seedlings of Capsicum cultivars under water stress paclobutrazol, triacontanol and other inhibitors improved the performance of days taken to formed open first flower.

\section{Duration of fruiting}

The data regarding mean duration of fruiting by different levels of paclobutrazol (days) are presented in (Table 2). The results elaborated that the duration of fruiting (days) was significantly $(\mathrm{P}<0.05)$ influenced under increasing paclobutrazol concentration. The results indicated that highest (31.33) duration of fruiting (days) was observed under the concentration of $150 \mathrm{mg}$ ai $\mathrm{L}^{-1}$ paclobutrazol while the lowest duration of fruiting (days) (21.66) was recorded under control treatment. Whereas the plant was treated with $90 \mathrm{mg}$ ai $\mathrm{L}^{-1}$ paclobutrazol was observed (27.33) in duration of fruiting (days). Whereas, the plant was treated with $60 \mathrm{mg}$ ai $\mathrm{L}^{-1}$ paclobutrazol was showed (25.33) in duration of fruiting (days). The results revealed that the plant was treated with 30 $\mathrm{mg}$ ai $\mathrm{L}^{-1}$ paclobutrazol was noted (25.00) duration of fruiting (days).

Increasing paclobutrazol concentrations decreased fruit duration. Plants treated with the highest sprayed paclobutrazol concentration exhibited fruit duration $12 \%$ smaller than untreated plants. The number of red fruits increased as the paclobutrazol drench concentrations increased. Earliness in harvest maturity in paclobutrazol treated tomato plants has been reported [29]. Further results revealed that the plant was treated with $30 \mathrm{mg}$ ai $\mathrm{L}^{-1}$ paclobutrazol was noted 4.60 life cycle. The results further indicated the lowest life cycle (4.26) was recorded under control treatment where no paclobutrazol was applied.

\section{Life cycle of plant (month)}

The data regarding life cycle of plant (month) as affected by different paclobutrazol levels are showed in (Table 1 ). The results of the analysis of variance illustrated that the life cycle of plant (month) was significantly $\quad(\mathrm{P}<0.05)$ influenced under increasing paclobutrazol concentration. The shortest life cycle of plan (month) (4.26) was recorded under control treatment while the longest life 
cycle of plant (month) in chilli determined in this experiment was 6.20 days when chilli plants were supplied with $150 \mathrm{mg}$ ai $\mathrm{L}^{-1}$ paclobutrazol. The life cycle of plant (month) significant decreased to 5.93 and 5.53 in treatment comprised of $120 \mathrm{mg}$ ai $\mathrm{L}^{-1}$ paclobutrazol $90 \quad \mathrm{mg}$ ai $\mathrm{L}^{-1}$ paclobutrazol, respectively. The life cycle of plant (month) further reduced to 4.93 and 4.60 in treatments comprised of $60 \mathrm{mg}$ ai $\mathrm{L}^{-1}$ paclobutrazol and $30 \mathrm{mg}$ ai $\mathrm{L}^{-1}$ paclobutrazol, respectively. The results showed that paclobutrazol application showed a remarkable impact on the life cycle of plant (month) in chillies.

The obtained data's are agreement with the outputs of [30], investigated the effect of plant growth regulators on callus induction and differentiation from cotyledons of Capsicum annuum. Paclobutrazol promoted root formation from callus and formed life cycle. Combinations of growth regulators had synergistic effects on life cycle as the root formation is the basic component of life cycle of plant.

\section{Conclusion}

The experiment was concluded that the paclobutrazol concentration up to $150 \mathrm{mg}$ ai $\mathrm{L}^{-1}$ significantly observed greater and obviously better then overall other concentrations. Therefore, paclobutrazol comprised $150 \mathrm{mg}$ ai $\mathrm{L}^{-1}$ will be recommended and suggested for better economic yield and quality production.

\section{Authors' contributions}

Conceived and designed the experiments: Z Ullah, AA Baloch \& N Ali, Performed the experiments: AA Baloch, Analyzed the data: Z Ullah, $\mathrm{K}$ Ullah, $\mathrm{S}$ Ahmad, $\mathrm{H}$ Baloch \& S Jaffar, Contributed materials/ analysis/ tools: AR Reki, A Jabbar \& ZU haq, Wrote the paper: Z Ullah \& N Ali.

\section{References}

1. Moscone EA, Scaldaferro MA, Grabiele M, Cecchini NM, Sanchez GY, Jarret R, Davina JR, Ducasse DA, Barboza GE \& Ehrendorfer F (2007). The evolution of chilli peppers (Capsicum - Solanaceae): a cytogenetic perspective. Acta Hort 745: 137-170.
2. Stummel JR \& Bosland P (2007). Ornamental Pepper Capsicum annuum. Flower Breeding and Genetics: Issues, Challenges and Opportunities for the $21^{\text {st }}$ Century (Anderson NO, ed.). Springer Dordrecht 561-599.

3. Rego ER, Rego MM, Finger FL, Cruz CD \& Casali VWD (2009). A diallel study of yield components and fruit quality in chilli pepper (Capsicum baccatum). Euphytica 168: 275-287.

4. Banon S, Gonzalez A, Cano EA, Franco JA \& Fernandez JA (2002). Growth development and colour response of potted Dianthus caryophyllus cv. Mondriaan to paclobutrazol treatment. Sci Hort 94: 371-377.

5. Mutlu SS \& Agan E (2015). Effects of paclobutrazol and pinching on ornamental pepper. Hort Technol 25(5): 657-664.

6. Ahmad I, Dole JM \& Whipker BE (2015). Paclobutrazolor uniconazole effects on ethylene sensitivity of potted ornamental plants and plugs. Sci Horti 192: 350-356.

7. Ribeiro WS (2016). Action of paclobutrazol and 1-MCP on the quality of ornamental species of Capsicum. The Fed Uni of Vicosa, pp 75.

8. Mansuroglu S, Karaguzel O, Ortacesme V \& Sayan MS (2009). Effect of paclobutrazol on flowering, leaf and flower colour of Consolida orientalis. Pak $J$ of Bot 41: 2323-2332.

9. Grossi S (2005). Effects of paclobutrazol on growth and fruiting characteristics of Pitanga ornamental pepper. Acta Hort 683: 333-336.

10. Pasian CC \& Benett M A (2004). Paclobutrazol soaked ornamental kale seeds produce short seedling. Acta Hort 631: 149-154.

11. Abdollahi M, Eshghi S, Tafazzoli E \& Moosavi N (2012). Effects of Paclobutrazol, Boric Acid and Zinc Sulfate on Vegetative and Reproductive Growth of Strawberry cv Selva. J Agr Sci Tech 14: 357-363.

12. Sipioni MS, Firmino JJL, Dias PHR \& Steiner F (2016). Paclobutrazol and cattle manure use improves the quality of pepper seedlings. Scientia Agraria Paranaensis 15(3):332-337.

13. Christiane DFMF, Lucas CDC, Teresa DC, Mirelle NDSS \& Fernando LF (2017). Evaluation of paclobutrazol 
application method on quality characteristics of ornamental pepper. Ornam Horti 23 (3): 307-310.

14. Christiane DFMF, Wellington SR, Mirelle NSS, Kharen PDOSP, Elizanilda Ramalho DR \& Fernando LF (2018). Growth and quality of potted ornamental peppers treated with paclobutrazol. Pesq agropec bras Brasília 53(3): 316-322.

15. Giovinazzo R, Souza MV \& Hartz TK (2001). Paclobutrazol responses with processing tomato in France. Acta Hort 54(2): 355-358.

16. Gomez KA \& Gomez AA (1984). Statistics for Agricultural Research (Second Edition). John Willey and Sons New York.

17. Abd El-Aal MMM \& Mohamed YFY (2017). Article no IJPSS 17(6): 1-22.

18. Chutichudet B, Chutichudat P, Boontiang $\mathrm{K}$ \& Chanaboon $\mathrm{T}$ (2006). Effect of Chemical Paclobutrazol on Fruit Development, Quality and Fruit Yield of Kaew Mango (Mangifera indica L.) in Northeast Thailand. Pak J Bio Sci 9: 717722.

19. Khan MA, Hussain SI, Tariq M \& Shah AH (2001). Effect of paclobutrazol on plant growth and yield of pepper. Pak $J$ Agri Res 10(1): 53-55.

20. Mahmoud RS \& Mohamed EE (2015). Rep Opinion 7(11):19-29] (ISSN: 15539873).

21. Moraes PJ, Grossi JAS, Tinoco SA, Silva DJ, Cecon HPR \& Barbosa JG (2005). Ornamental Tomato Growth and Fruiting Response to Paclobutrazol. Proc Vth IS on New Flor Crops Acta Hort 327-331.

22. Berova M \& Zlatev Z (2000). Physiological response and yield of paclobutrazol treated tomato plants (Lycopersicon esculentum Mill.). Plant Growth Regul 30(2): 117-123.

23. Lolaei A, Mobasheri S, Bemana R \& Teymori N (2013). Role of Paclobutrazol on Vegetative and Sexual Growth of Plants. Intern J Agri and Crop Sci 5(9): 958-961.

24. Saraiva JA, Moraes PJ, Tinoco SA, Barbosa JG, Finger FL \& Cecon PR (2005). Effects of paclobutrazol on growth and fruiting characteristics of 'pitanga' ornamental pepper. Vth International Symposium on New Floricultural Crops, ISHS Acta Hort 683: 333-336.

25. Christiane FMF, Lucas CC, Wellington SR, Teresa DC, Mirelle NS \& Fernando LF (2017). Evaluation of paclobutrazol application method on quality characteristics of ornamental pepper. Depart Bio Veg Vicosa-MG Brazil 23(3): 307-310.

26. El-Masry TA (2000). Growth, yield and fruit quality response in sweet pepper to varying rates of potassium fertilization and different concentrations of paclobutrazol foliar application. Ann Agri Sci 38(2): 1147-1157.

27. Chutichudet B, Chutichudet $P$ \& Chanaboon $T$ (2007). Effect of Chemical Paclobutrazol on Growth, Yield and Quality of Okra (Abelmoschus esculentus L.) "Har Lium" Cultivar. Northeast Thailand Vol 10(3): 433-438.

28. Thakur A, Thakur PS \& Kanaujia SP (2000). Effect of bioregulators, bioextracts and potassium on growth and related attributes in bell pepper (Capsicum annuum) varieties under water stress. Ind J Agri Sci 70(4): 255-258.

29. Giovinazzo R, Souza MV \& Hartz TK (2001). Paclobutrazol responses with processing tomato in France. Acta Hort 542:355-358.

30. Yang JW, Yan HW \& GuangLan QY (2001). Callus induction and differentiation from the cotyledon of Capsicum annuum L. J Jilin Agri Uni 22(2): 51-55. 